University of Nebraska - Lincoln

DigitalCommons@University of Nebraska - Lincoln News Rediscovered

Adrian S. Wisnicki

Follow this and additional works at: https://digitalcommons.unl.edu/englishfacpubs

Part of the Comparative Literature Commons, English Language and Literature Commons, Modern Literature Commons, and the Reading and Language Commons

This Article is brought to you for free and open access by the English, Department of at DigitalCommons@University of Nebraska - Lincoln. It has been accepted for inclusion in Faculty Publications -Department of English by an authorized administrator of DigitalCommons@University of Nebraska - Lincoln. 


\title{
A Trove of New Works by Thomas Pynchon? Bomarc Service News Rediscovered
}

\author{
Adrian Wisnicki
}

Early in 1960, after having graduated from Cornell and while writing $V$., Thomas Pynchon moved to Seattle and began working for the Boeing Airplane Company. What Pynchon did while working at Boeing has puzzled scholars almost from the moment of the very private author's literary debut. When we try to delve into his stint at Boeing first mentioned by Lewis Nichols and Dick Schaap-we reach dead ends or find conflicting information. Yet Pynchon's time at Boeing is perhaps the most documented period of his life, and over the years a number of interesting (though not always accurate) bits of information have emerged.

Here I first recount the previous scholarship on this phase of Pynchon's career and consider its weaknesses. Next, I detail my own research and conclusions, namely that while at Boeing, Pynchon wrote primarily for an internal newsletter - none of whose articles have bylines - called Bomarc Service News (first mentioned by Richard Lane), and that in two and a half years of work he produced some twenty-five to thirty technical articles for this newsletter. I discuss these articles and the criteria for attributing their authorship, and finish with a comprehensive annotated list of those I attribute to Pynchon. In this way, I hope to solve what has been one of the longest-running mysteries in Pynchon scholarship, as well as bring to light the depth and range of Pynchon's expertise on the Bomarc missile-an expertise which almost certainly inspired and underlies Gravity's Rainbow.

In "The Quest for Pynchon," Mathew Winston provides the first substantial, if brief, discussion of Pynchon's work for Boeing. Though Winston's essay is not particularly well-documented, he does give Pynchon's dates of employment as February 2, 1960, to September 13, 1962. What did Pynchon do during this time? Winston gives only a vague account: Pynchon worked "not as editor of a house organ . . . but as an 'engineering aide' who collaborated with others on writing technical documents" (284-85). In half a sentence Winston first refutes a suggestion Nichols had made, then drops a tantalizing hint, but provides no evidence for his claims and leaves many questions unanswered. 
Five years after Winston, David Cowart develops the picture further. Cowart locates one of Pynchon's colleagues at Boeing, Walter Bailey, who worked "'a couple of desks over" from Pynchon "in Boeing's giant Developmental Center." According to Bailey, Pynchon "wrote for an intramural sheet called the 'Minuteman Field Service News' (to be distinguished from the company's official house organ, The Boeing News)." Specifically, the two men "worked in the Minuteman Logistics Support Program," and Pynchon had "a 'Secret' clearance." Pynchon, Bailey recalls, was an introvert, had few friends at Boeing, and, while working, would occasionally "shroud himself in the enormous stiff sheets of paper used for engineering drawings and work within this cocoon, like an aerospace Bartleby, by whatever light filtered in" (96). The men became friendly when "Bailey made a casual literary reference one day, which generated an immediate and enthusiastic response from Pynchon." Pynchon, Bailey discovered, was "very literate"" and also well-versed in "technical matters" (97). Unfortunately, Bailey's reminiscences end there lexcept for a further brief reference, relegated to an endnote, to Pynchon's technical competence), and Cowart, like Winston, fails to inquire further - about either Minuteman Field Service News or, more intriguingly, what Pynchon wrote for it.

Clifford Mead's comprehensive Pynchon bibliography does not include Minuteman Field Service News or any Pynchon articles it might contain. Mead does list one article from Pynchon's time at Boeing, "Togetherness," from the December 1960 issue of Aerospace Safety." I discuss this article below, so for now will note only that its byline identifies the author as "Thomas H. [sic] Pynchon, Bomarc Aero-Space Dept., Boeing Airplane Co., Seattle" (6), and that the article (of which Mead reproduces the first two pages) concerns safety issues in airlifting the Bomarc IM-99A missile.

Donn Fry, a writer for the Seattle Times, picks up the Boeing thread next. In a short piece on Pynchon's life, published alongside a review of Vineland by David Shields, Fry gives Pynchon's Seattle address (obtained from city directories of the early sixties) as " $47091 / 2$ Ninth Ave. N.E., in the University District" (L7), recaps the Cowart material, ${ }^{2}$ and adds the reminiscences of Kenneth Calkins, a one-time writer for Boeing Magazine. Calkins, who describes Pynchon as having long hair and a "Wyatt Earp-type handlebar mustache," once complimented Pynchon "on an article he had written for another Boeing publication," though Fry does not specify which one: "He did a story on the soldering of electronic circuitry, which I have absolutely no interest in. ... But I thought, my gosh, how can a guy make a story about this so 
interesting?"' (L7). Pynchon's technical writing, apparently, was so good that Calkins recalls a particular article thirty years later.

Finally, Richard Lane puts yet another spin on the Boeing story, in "Boeing, Boeing," a section of his now defunct website, The Pynchon Files. Lane, too, gives Pynchon's Seattle address, says that Pynchon worked for Boeing Aerospace Operations, but claims that Boeing denies Pynchon was ever an employee. Lane, however, locates Pynchon's name in the Boeing Internal Directories for 1961 and 1962 (both entries are reproduced on the website, though the numerical codes that follow Pynchon's name are not explained). More important, Lane asserts that Pynchon's first job at Boeing was with the Bomarc Service Information Unit, which published Bomarc Service News. Work for this newsletter, Lane continues, was done "by the book":

Work was assigned, the subject studied, for example a loading-pin mechanism, then a visit was made to the on-site manufacturing and application of the pin, a chat with the design engineers, then the writing up of the paper, using a Boeing style-book as reference, before editorial approval.

Further, Lane speculates that Pynchon's Aerospace Safety article first appeared in Bomarc Service News; he adds, as a final note, that by February 1962, Pynchon was working for the Minuteman Field Support Unit. Unfortunately, though Lane seems to have had contact with someone at Boeing to gather his information, he fails to cite his sources (besides the internal directories), using instead such phrases as "As described to the Files." Nor does he produce Bomarc Service News.

I have dwelt on this material to emphasize a number of problems. First, most of the information is based not on primary documents (Aerospace Safety and Boeing's directories being the exceptions) but on oral recollections, fifteen to thirty years after the event. Winston and Lane do not identify their oral sources at all, but instead make only unsubstantiated assertions. For example, Winston - without any gesture toward evidence-merely declares the dates of Pynchon's employment. Though there seems to be no reason to doubt them, Winston gives us no reason to accept them. Yet most subsequent scholars (with one exception: see note 2) unhesitatingly repeat them. Second, the articles contain conflicting reports of where Pynchon worked within Boeing and of what kind of work he did-though the byline and simple existence of "Togetherness" both indicate that writing for Boeing's Aero-Space Department about the Bomarc missile was at least one of his jobs. Third, and most important, even if we accept Winston's dates and the 
claim that Pynchon's primary work was technical writing, the fact remains that, for two and a half years of Pynchon's labor, we have only one known article.

So where are the rest?

Though the question seems easy to answer with some simple library research, it requires extensive work in the long run. Part of the confusion stems from the fact that previous scholars associate Pynchon with at least four publications - The Boeing News, Minuteman Fie/d Service News, Bomarc Service News and Aerospace Safety. Aerospace Safety (F/ying Safety until June 1960) was issued by the United States Air Force Department, not by Boeing, and so was probably not Pynchon's main writing outlet. The other three were Boeing publications and, as it turns out, just a few of the many the company issued in the early 1960s. According to Michael J. Lombardi, the manager and historian at Boeing Historical Services, each military program at Boeing published its own field service update-like Minuteman Field Service News and Bomarc Service News - all of which were internal newsletters (TC). The Boeing News ceased publication as such in 1944, becoming The Boeing Magazine, which ran from 1945 to 1970. The Boeing Magazine was available to the public (it can be found today in many libraries across the U.S., including the Science, Industry and Business Library of the New York Public Library) and was written in a simple, matter-of-fact style for a general audience. It covers a wide variety of topics, including space exploration, wind tunnels, supersonic jets and Chinook helicopters. It contains articles on the Minuteman missile, but almost all are by Thomas Reidinger, whose work for the magazine antedates Pynchon's time at Boeing (if we accept Winston's dates). The magazine also contains articles on Bomarc missiles, including at least one by Kenneth Calkins. Articles in The Boeing Magazine are almost always signed, yet none between the years 1960 and 1962 are signed by Pynchon.

Minuteman Field Service News, as it turns out, was actually called Minuteman Service News. The development of the Minuteman missile began in 1958, and the missile, "formally known as the SM-80, was a second generation intercontinental ballistic missile (ICBM) using solid propellants rather than liquid fuels. It was smaller and easier to maintain than the Atlas and Titan ICBMs and through its use of solid propellants could be launched almost instantaneously" (Boeing LGM-30A). Minuteman Service News provided a forum to gather and publish support information pertinent to maintaining and using the missile. As mentioned, the newsletter was an internal publication. Consequently, unlike those in The Boeing Magazine, the articles in Minuteman Service News are highly technical, and most have no bylines. Further, since 
Minuteman Service News was not for the general public, few copies have survived; the newsletter seems to be available in only two places in the United States-Boeing's Historical Services and the Smithsonian's National Air and Space Museum Archives (NASM), though the set at NASM is missing the first issue (November-December 1962) and a number of later issues. In any case, as the date of the first issue shows, Minuteman Service News began publication at least two months after Pynchon probably left Boeing.

Bomarc Service News, another internal Boeing newsletter, pertained to the precursors of the Minuteman. Bomarc missiles came in two versions: the IM-99A, with a 200-mile range, and, later, the IM-99B, with a 400-mile range. Both Bomarcs were ground-to-air solid-fueled supersonic missiles, "the world's first long-range anti-aircraft missiles, and the first missiles that Boeing mass produced." They were "housed on a constant combat-ready basis in individual launch shelters in remote areas"; "[t]he alert signal could fire the missiles around the country in 30 seconds" (Brief History). So information about the missiles was sensitive. The cover of each issue of Bomarc Service News warns that the newsletter is "not for public release," and the contents page of each issue clarifies: "Although the BOMARC SERVICE NEWS is not classified, existing rules regarding indiscriminate or unauthorized dissemination of military information are still applicable." The contents themselves consist of unsigned technical articles (generally accompanied by technical diagrams, illustrations or photographs), most no more than a few pages. Like those in Minuteman Service News, the articles in Bomarc Service News usually have a serious tone, unlike the lighter tone of articles in other aeronautical publications of the period, such as Approach: The Naval Aviation Safety Review and Aerospace Accident and Maintenance Review. Each issue of Bomarc Service News is between twelve and twenty-four pages, and has a number of regular columns, including a note from the editor, F[ield] S[ervice] R[eport] Briefs, and Safety Information. The newsletter appeared every other month from April to December 1959, then monthly until its final issue, No. 41, December 1962-January 1963-dates nearly concurrent with Pynchon's reported time at Boeing. Further, as each contents page also states, the newsletter was published by Boeing's Aero-Space Division, ${ }^{3}$ Pynchon's department, as we know from his Aerospace Safety byline.

Was Bomarc Service News the Boeing publication for which Pynchon wrote? Admittedly, the evidence I have so far presented is scant. Only Lane mentions the newsletter, and his documentation leaves much to be desired. Equally, the connection to the Aero-Space Division may be insignificant; and again, none of the articles in Bomarc Service News have bylines. Further complicating the investigation, as 
I learned when, prompted by Lane's claim, I began to search for Bomarc Service News, the newsletter, like Minuteman Service News, survives in only a few places in the United States. It is available at the U.S. Air Force's Air University Library in Alabama, at NASM and at Boeing. The Air University Library will not copy the newsletter for scholars who are not on site; NASM has only about one-third of the newsletter's run; and Boeing (which does have the full set) charges $\$ 100$ per hour for photocopying and $\$ 250$ for licensing. ${ }^{4}$ Thus, to obtain the 500-plus pages of the newsletter that cover Pynchon's time at Boeing ${ }^{5}$ requires a fair amount of effort and money.

That said, during my research I did get two big breaks. The first and most important of these came while my set of Bomarc Service News was still incomplete, when I had only the material available from NASM. Though Bomarc Service News prints no bylines and mentions none of its staff writers by name, the contents page of each issue does list a number of ranking personnel in the Aero-Space Division, including the Bomarc Service News editor, E. A. Hixson. Using an internet addressfinder, I was able to locate and contact Mr. Hixson, who still lives in Washington state. He kindly confirmed that Pynchon had written for Bomarc Service News and shared some memories with me. He remembered Pynchon as "a very neat person, slender with a small mustache," and as "a very diligent researcher" (L 4 Apr., L 8 Jun.). Further, Mr. Hixson elucidated a number of points pertaining to the writing of Bomarc Service News. First, along with Mr. Hixson (who wrote only the editor's column), there were five to six writers on the Bomarc Service News staff. Second, "articles were not always completed in one month"; "some took several months of research." Third, as to what was written about, "there were various topics and the writers might select one or [Mr. Hixson] would advise as to the material." ${ }^{\prime 6}$ And last, articles by the Bomarc Service News staff also appeared in other publications, including Aerospace Safety and Aerospace Accident and Maintenance Review (L 2 Jun.).

My second break came when Mr. Hixson put me in touch with Michael Lombardi of Boeing Historical Services. Mr. Lombardi confirmed that Boeing has a complete run of Bomarc Service News, that Pynchon wrote for the newsletter, and that Boeing has "no other information concerning Pynchon," since "he managed to be a recluse even while working at Boeing" (L). Thus I gathered a fair amount of important information. By contacting Boeing's licensing division, I was able to complete my set of Bomarc Service News.

So what about Pynchon's contributions to the newsletter? Thirtytwo issues of Bomarc Service News, totaling more than 500 pages, cover Pynchon's time at Boeing (No. 8, March 1960, through No. 39, 
October 1962). Excluding the editor's notes and the Field Service Reports (which latter were "sent in to the home office at Seattle by technical representatives in the field" [BSN 7: 13]), a typical issue contains four to five major articles (one or more pages each) and two to three shorter ones (less than a page each). Based on these numbers and on the fact that there were five to six writers on the staff, it seems likely that Pynchon would write no more than one or two articles per issue and, since some articles took longer than a month to complete, that he would have no articles in some issues. Contrary to Lane's surmise, "Togetherness" does not appear in Bomarc Service News. But a number of articles from Bomarc Service News, and a few written by the staff but not published in the newsletter do appear in Aerospace Safety and in Aerospace Accident and Maintenance Review, ${ }^{7}$ and at least one appears in Approach: The Naval Aviation Safety Review.

To establish the criteria for distinguishing which articles in Bomarc Service News Pynchon may have written, I shall look first at his Aerospace Safety article. Though some readers may find "Togetherness" dry compared with Pynchon's fiction, the article is not strictly technical. Pynchon's purpose is to discuss the safety precautions necessary when airlifting the IM-99A Bomarc missile, yet seemingly excess material repeatedly creeps in. Consider the following passage:

As this article goes to press, the safety record of Bomarc airlifts can be summed up in four words: so far, so good. You may recall, however, the optimist who jumped off the top of a New York office building. He was heard to yell the same thing as he passed the 20th floor: so far, so good.

(6)

In the midst of a serious discussion, Pynchon uses this analogyincongruous with the topic, yet surprisingly illuminating and humorous. Another stylistic feature of the passage also recurs throughout the article: in addition to third-person exposition, Pynchon often uses the second person to address the reader directly. Further, he uses a fair number of em dashes throughout the article (em dashes, along with ellipses, are prominent in Gravity's Rainbow and Mason \& Dixon), and refers to Technical Manual T.0. 21-IM99A-2-2 as "the bible" for the airlifting process (7). Finally, although Pynchon's purpose is to inform readers about safety problems, he occasionally assumes an instructive (even didactic) tone, aiming to prevent as well as inform: "The moral is simply that everybody engaged in the operation should be told beforehand what each signal means and the information checked and double checked before on or offloading ever begins" (8). Pynchon 
writes from the perspective of someone who knows the correct procedure and wants to instruct the reader.

Now for Bomarc Service News. A glance at any issue shows that Bomarc Service News delivers exactly what its title promises - a series of articles on various service issues related to the Bomarc missile, from technical information about missile components, to comparison of the IM-99A and IM-99B, to discussion of safety concerns and hazard prevention. ${ }^{8}$ For example, the April 1962 issue (besides the Field Service Briefs, which include notes on "Boost Motor Tiedown Cables," "Mismatching of MIU cables" and "Triode in Demodulator Assembly") includes the following articles, each giving what the title suggests: "Marking of Hydraulic Plumbing," "Gat Cooling Air Interlock Switch," "MIU Plug Problems" and "Filling IM-99A Oxidizer Tanks." Two quotations will illustrate the style and content. According to the hydraulic-plumbing article: "The hydraulic plumbing for the IM-99B launcher erector, hydraulic skid, and the interconnect plumbing is marked in accordance with MIL-STD-101A. Markings were installed to provide identification, indicate working pressure, and to show the direction of fluid flow" (BSN 33: 2). The oxidizer-tanks article informs us:

By this time, we are convinced that we would have pressure drop in the lines when oxidizer started flowing from trailer to missile. However, we are surprised to learn how much. The engineer tells us that, with an initial nitrogen pressure of $115 \mathrm{psig}$ during flow, the pressure in the oxidizer line in the vicinity of the separation diaphragm will be approximately 35 psig. (BSN 33: 10)

In short, the articles provide highly detailed information, "by the book" (to quote Richard Lane), and to the point, but perhaps dry to the nonspecialist.

A closer look at the issue, however, challenges such a generalization. "MIU Plug Problems," for example - which at first seems similar to the other articles in the issue-contains the following passage:

Those who design electrical cables become-not unreasonably - concerned when these cables are damaged in use. For a hypersensitive few, perhaps, the only significant difference between the cable assembly one has designed and one's own offspring is the $\$ 600$ tax deduction; every tear in a protective covering, every deviation of a plug from the perfectly circular, every bent pin or contaminated socket is like a judo chop, inflicted by an invisible but tireless adversary; an adversary who haunts one's uglier 
nightmares, wears AF blue and is named The User. Ask one of these delicate souls what he thinks The User has been doing with the MIU cable plugs lately and most of the answers you get will be unprintable. (BSN 33: 6)

Not quite by the book, to be sure. The article also contains a number of em dashes, while the rest of the issue has only one or two more. There are a few bullet points as well, really little triangles that point to the right-reminiscent, perhaps, of the pointing-hand dingbats in the epilogue of $V$. - especially noticeable since builet points elsewhere in Bomarc Service News are marked with the standard dots. Finally, the writer of this article even creates a new word: "Haste results from an affliction you could call 'teardownitis': the desire, once missile checkout is completed, to be over and done with the job as quickly as possible" (BSN 33: 6).

Yet, admittedly, these are nuances in a somewhat engaging though still quite technical article. So let us turn back two issues, to February 1962. Among the articles here are "“Teflon' in Depth," "IM-99B Radome Protective Covers," "New Inspection Intervals for IM-99A," etc. The Teflon article (the first long article in the issue) opens with a surprising passage worth quoting in full:

Where do rumors come from? Usually, the origin of a rumor is a mystery. Studies have been made on this subject, but there seems to be no explanation for the fact that the same rumor will suddenly and simultaneously appear in widely separated areas.

A case in point is the story that "happened" in several places when automatic transmissions were introduced. There was this fellow with a new car with hydramatic drive who couldn't get it started. He flagged down a woman driver and asked if she would give him a push so he could get the motor going. He explained to her that she would have to push him at 35 $\mathrm{mph}$ before his engine would turn over fast enough for ignition. The woman backs down the street about half a block, and with a running start she piles into the rear end of his new car at $35 \mathrm{mph}$. Remember that one?

Some rumors are downright cruel and seem to be perpetuated by a relentless sadistic force. A story that has been labeled a "cruel hoax" by the Better Business Bureau, makes the rounds yearly. . . . to the effect that if smokers save the colored cellophane ribbons from cigarette packs and turn a stipulated amount of them in to a certain (usually unnamed) agency, the cigarette company will supply a seeing eye dog to a blind person. This malicious rumor is a lie. . . . but in spite of the fact that the national and local Better Business Bureaus continually fight the story, women's clubs all 
over the United States are still being hoodwinked into collecting cellophane ribbons. (BSN 31: 3; ellipses in original)

Here instead of em dashes there are ellipses (prominent, as noted above, in Gravity's Rainbow and Mason \& Dixon), which also appear only rarely in Bomarc Service News. More striking, of course, is the passage itself-especially in the context of the entire issue. We get a casual, conversational address to the reader ("Remember that one?") and some quirky material, as in "Togetherness," rather in excess of the topic. ${ }^{9}$

The Safety Information article in this issue is even more startling. A drawing of the Mad Hatter from Alice in Wonderland greets the reader from the upper right-hand corner of the page, and the article's title makes the reference explicit: "The Mad Hatter and the Mercury Wetted Relays." Again I quote the opening:

Perhaps many of you lovers of Lewis Carroll's "Alice in Wonderland" have been wondering what made the Mad Hatter mad. Well-you need wonder no longer. He was suffering from chronic mercurialism, a disease common in the hat-making trade of that era (and to a lesser extent, still with us today).

The process of using mercury in felting was known in the times of the Greek and Roman empires and perhaps by oriental shepherds even earlier in history. Fine hairs of the fur of rabbits, hares, and other animals used in making felt are smooth and straight. By treating them with acid nitrate of mercury, the hairs are made limp and twisted, which aids the felting process.

This occupational disease among felt-hat workers is also known as "hatter's shakes," because chronic mercury poisoning affects the nervous system, causing characteristic muscular tremors. Since mental disturbances may also occur, the "Mad Hatter" character has a real-life bases - as does the expression "as mad as a hatter." (BSN 31: 16)

The Mad Hatter suffering from chronic mercurialism? And, it is "still with us today"? What does this have to do with the Bomarc missile? Quite a bit, it turns out, because what happened to the Mad Hatter could also happen to a Bomarc technician accidentally exposed to mercury:

The subject of mercury comes up here because of a potential hazard that exists in the IM-99B IMSOC rooms. Located in each room are 150 etched cards known as "Code 834 Mercury Wetted Relays" - and each card includes six wire wrapped glass capsules. [. . .] 
Occasionally capsules will explode while in place, spewing mercury in the cabinet. (BSN 31: 16)

Quirky excess material suddenly becomes illuminating. In addition, the first passage above contains erudite references to the Greeks, the Romans and the ancient Orient. Later in the article, there are more em dashes, triangular bullet points, and references to the Roman mines in Almaden, to Pliny the Elder, and to sixteenth-century Siena. That is, the articles display the constant and easy shifting of narrative registers and mixing of the arcane and the popular that also mark Pynchon's fiction.

We may develop these observations further by turning to the September 1962 Bomarc Service News. This issue contains "IM-99B ELE Battery Venting," "Hydrazine Tank Cartridge Replacement," "Test Point No. $\rightarrow$ Switch No. $\rightarrow$ Location," "A\&M Cart Improvement," "Correction of Multiple LSM Readouts," a Service Briefs section and a Safety Information article, "Know Cadmium." Again each title gives a fair idea of the article's content and style, but again there is an exception. "Hydrazine Tank Cartridge Replacement," for example, opens as follows:

"B" missile APU fuel tanks are filled at the factory with hydrazine and sealed with a burst diaphragm cartridge. Along with periodic weight checks, tanks are also checked for leakage. In the past, any leaking tanks were returned to the vendor for repair and, if necessary, for refilling.

With the release of T.O. supplements 21-IM99B-2J-2C and 21-IM99B$2 \mathrm{FJ}-2 \mathrm{C}$, ammonia room personnel at " $\mathrm{B}$ " bases are now authorized to repair leaking tanks by replacing the burst diaphragm cartridge. Boeing conducted an OJT course for base personnel back in June. In case you may have forgotten some of the details, we'd like to review and elaborate on a few of the more important points. (BSN 38: 3)

This seems by the book and written for specialists. The only minimally distinctive element is the switch to second person in the last sentence. But when the writer goes on to discuss hydrazine safety, the style changes:

As far as the vapor business goes, then, hydrazine is like gasoline. You don't stick your head inside a gas tank so you can inhale its delightful aroma; nor do you light up your favorite weed where there are gasoline fumes around. In fact if you do any smoking at all around either gasoline or hydrazine, we guarantee you'll be enjoying it less. (BSN 38: 3) 
The shift is startling. Though only a paragraph separates this passage from the previous one, the writing exhibits a new level of vitality. Again it uses the second person, but now the tone is decidedly conversational (sarcastic even, in its play on the well-known Camel cigarette slogan) and instructive, much like "Togetherness." More significant, the allusion to a "favorite weed" is certainly suggestive. From here the writer moves to a brief history lesson on hydrazine:

Anhydrous hydrazine is nothing new, exotic, or far out: it's been around since 1894, when a chemist named de Bruyn first produced it in his laboratory. The stuff is a close relative both to hydrazine hydrate, which the Germans used in the old V-2 rocket, and to anhydrous ammonia, which farmers have been using for years as a fertilizer. (BSN 38: 3)

As in the Mad Hatter article, the writer effortlessly shifts narrative registers and displays historical erudition, including here a reference to the V-2-central, of course, to Gravity's Rainbow.

Consequently, if we assume Pynchon was one of the staff writers for Bomarc Service News, as Mr. Hixson's evidence seems to warrant, it becomes rather easy to identify articles he probably wrote. Even a cursory glance through the 1960-1962 issues reveals that certain articles stand out against the background of generally dry and monotonous surrounding ones. The probable Pynchon articles are characterized by free use of the second person, by frequent shifts of narrative register, by surprising connections among arcane facts, by occasional literary references (though that to the Mad Hatter may be somewhat exceptional), and by a conversational/instructive tone consistent with that of "Togetherness." Other telling traits of style and subject are discussed below.

The argument and these criteria gain force when we remember what Calkins says about Pynchon in Fry's article: "'He did a story on the soldering of electronic circuitry, which I have absolutely no interest in. . . . But I thought, my gosh, how can a guy make a story about this so interesting?'" The article to which Calkins refers, titled simply "Soldering," is the cover story for the August 1961 issue of Bomarc Service News; it is reprinted, again as the cover story, in the April 1962 issue of Aerospace Accident and Maintenance Review (where it is credited only as "courtesy of Bomarc Service News Aero-Space Division"). Here is the opening paragraph:

Soldering is a skill which depends primarily on experience. Any printed discussion of the subject is therefore limited in how much it can really tell a prospective solderer about the down-to-earth aspects of his craft. So 
don't expect this article to be any sort of do-it-yourself instruction sheet. Whenever you are called upon to do electronic circuit soldering, no texteither formal or informal-should ever be regarded as a substitute for solid experience. (BSN 25: 3)

Once more Pynchon assumes the instructive stance of someone in the know (a stance consistent in those articles I attribute to him but rare in other Bomarc Service News articles), addresses the reader conversationally, and uses em dashes. It is also easy to see why Calkins can remember the article thirty years after the fact. First, as mentioned, it makes the cover of both newsletters. Second, the article is abnormally long for Bomarc Service News (nine out of sixteen pages). Third, though the article is highly detailed and technical, Pynchon is eloquent, engaging and occasionally humorous:

Notice that with only one exception, any given composition of solder will have two change-of-state points, a solidus point and a liquidus point. The solidus point is the point at which, with rising temperature, solder leaves the solid state. The liquidus point is the point at which, again with rising temperature, solder becomes completely liquid. Between the two points is a temperature range known variously as the pasty state, the state of plasticity, or-more succinctly-mush. (BSN 25:4)

Such moments-though sometimes subtle, as here-enliven the technical discussion. We can begin to understand how the article might have produced a lasting impression.

Yet the Bomarc material does present some difficulties. At first encounter, one might tend to see Pynchon everywhere or nowhere in Bomarc Service News. Although there are obvious differences between most of the articles I attribute to Pynchon and those by other staff writers (as noted above), the differentiae are not absolute. Other writers occasionally use ellipses and em dashes, so these stylistic nuances alone offer no aid in identifying articles, especially shorter pieces, as Pynchon's. Other writers also use bullet-point arrows occasionally, and Pynchon sometimes uses bullet-point dots, as in "Soldering." Further, Pynchon's writing here, though well crafted and often humorous, does not attain the heights of $V$. or Gravity's Rainbow. A reader accustomed to Pynchon's fiction may have to read carefully to recognize his writing in the less colorful pieces. Finally, other Bomarc Service News writers sometimes make stabs at endowing their technical material with a little literary grace: 
Two Air Force sergeants were enjoying their cups of coffee and talking about everything under the sun, but after a while they were again at their favorite subject, their newly-bought cars. They debated their purchases pro and con. One sergeant was certain his car would not need any major repairs during the first 30,000 miles. The other also had a good reason why he bought his special type of car, his particular make of car had low depreciation and offered long service life. ("Reliability," BSN 14:9)

Such passages may tempt the reader hunting for Pynchon articles. Yet alongside Pynchon's work, even the graces in other Bomarc Service News articles can seem somehow stilted and less imaginative. In depicting these sergeants, this writer uses a cliché, "everything under the sun"; and the passage sounds more like a car advertisement by the end than like quality writing.

But these reservations do not apply in the majority of cases, especially to articles longer than a page. Over the two and a half years Pynchon writes for Bomarc Service News (and the presence of articles I attribute to Pynchon does accord with the dates Winston gives; but see note 201, his articles almost always stand out in the context of the newsletter, consistent both on the larger scale and at the level of nuance. The nuances include not only bullet-point arrows, em dashes and ellipses, but penchants for scare quotes, for semantic debate, and for Greek and Latin etymologies (see, for example, "1,000,000,000 Miles = One Gigamile"), for referring to this or that technical manual as the "bible" or the "Book" (see, for example, "Maintainability, Part 2") and for cracking jokes about beer or inhalants (as we saw, for example, in "Hydrazine Tank Cartridge Replacement").

The articles I attribute to Pynchon also display larger and more significant patterns in subject matter and style. While servicing Bomarc missiles is a complex business, and Bomarc Service News covers a wide array of topics and subtopics, Pynchon's articles focus on a limited number of themes. The most prominent of these are safety, reliability and maintainability (for example, testing for problems, component failures, vibration damage, accidents, vapor hazards and chemical contamination). Of course, given the scope of Bomarc Service News, other writers explore these themes too, but we find the longest and most consistent discussions in the articles I attribute to Pynchon. In addition to the topics, the articles are distinguished by their style, the conversational addresses to the reader and the emphatically instructive, even didactic, tone- of which I give one more memorable example:

Or take our hypothetical squadron again, with its $72 \%$ reliability. Suppose every man who performs maintenance on the system is only $99 \%$ 
perfect. Then every time an individual act of maintenance is performed on the weapon system the reliability is reduced a little more: $72.0 \%, 71.3 \%$, $70.6 \%, 69.9 \%$, and eventually down to zero.

"So what do they want," you're wondering. "They want me to be $100 \%$ perfect?"

Right. We want you to be $100 \%$ perfect. We'll admit it takes a lot of working at. But then, optimists that we are, we figure that's what you joined the Air Force to do: work. Work, learn and improve your own knowhow and ability in the process. And maybe acquire along the way a certain pride in the knowledge that you're doing a job only a tiny fraction of guys your age are even qualified to do.

Assuming this is the kind of technician you are, how can you become, and stay, $100 \%$ reliable?

By not ever being satisfied. By picking nits that haven't even been invented yet. By double-checking a job when it's done and raising hell if it's not done right. By having enough savvy to know exactly what "right" means. By following the TO, and trusting it as the final authority in maintenance matters. And, above and beyond this, by bringing to the maintenance you perform that "something extra" the TO doesn't always tell you how to do. ("Bomarc Reliability and You," BSN 39: 7-8)

In short, Pynchon lectures the reader, and the perfectionist bent exhibited here and repeatedly in other articles mirrors a biographical detail reported by Nichols: Pynchon "is a tireless researcher and, caught in a minor error, suffers the humiliation of the damned" (8).

Perhaps most important from a literary point of view, articles attributable to Pynchon contain erudite historical discussions. Some passages, for example, relate directly to Gravity's Rainbow:

Now about the time B-17 operations were in full swing, curious things were happening on the other side of the English Channel. Certain Nazi convoys were busy moving about the French countryside. Every now and again a convoy would pick out a spot, stop, and set up a launching site for something officially known as the A4 missile. We know it better, perhaps, as the V-2. ("Missile Ground Support Equipment," AAMR Dec. 1961:3)

Other passages might best be described as suggestive, such as the following discussion from "'Teflon' in Depth":

Teflon dates back to 1938 when the resins were first synthesized in Du Pont Company's laboratories. The initial compound was a polymer of tetrafluoroethylene (TFE), which is a chemical relative of "Freon" fluorocarbon propellants and refrigerants, and today is used as a standard 
refrigerant in home air conditioners and is also the most popular propellant in push-button aerosol packages.

In 1943, limited quantities of Teflon TFE-fluorocarbon were being produced and all of it was snapped up by the military. The Manhattan Project found it to be the only gasketing and valve-packing material suitable for specific atomic energy plant operations. The material was later used for proximity fuse nose cones in naval and artillery shells. (BSN 31:3-4)

Though the substance under discussion is Teflon, Pynchon readers will recall another passage, which runs in part: "Imipolex $G$ has proved to be nothing more-or less-sinister than a new plastic, an aromatic heterocyclic polymer, developed in 1939, years before its time, by one L. Jamf for IG Farben. [. . .] The origins of Imipolex $\mathrm{G}$ are traceable back to early research done at du Pont" (GR 249). It hardly takes an imaginative leap to see how, in terms of both chemical and historical information, the Teflon article could have provided creative inspiration for the mysterious Imipolex $\mathrm{G}$ in Gravity's Rainbow.

So the more one reads Bomarc Service News, the more one discovers ways Pynchon's work at Boeing seems to have inspired the creation of his fiction. One also gains a better understanding of the true range of Pynchon's engineering expertise, an expertise surpassing that displayed in even the more demanding technical passages of Gravity's Rainbow. If the newsletter seems wholly anonymous and technical at first, one eventually perceives a combination of larger patterns and stylistic nuances that makes it relatively easy to identify Pynchon's articles with some confidence, though a number of uncertainties necessarily remain.

Following is an annotated list of articles in Bomarc Service News that I believe Pynchon wrote, and of articles written by the Bomarc Service News "staff" but published elsewhere that I believe Pynchon also wrote. Based on the criteria I have outlined, I feel fairly certain about twenty-four pieces and somewhat uncertain about another ten. ${ }^{10}$ The total is rather large, but some of the articles are short, and their appearance follows the pattern I infer from Mr. Hixson's information: one or two Pynchon articles per issue, with some issues having no Pynchon articles at all. Thus this cache provides some twenty-five to thirty hitherto unknown (if not unsuspected) works by a great twentieth-century American author, and its rediscovery opens exciting new opportunities in Pynchon scholarship. 


\section{Annotated Bibliography}

\section{Probable Pynchon Articles}

"Vibration Testing." Bomarc Service News 8 (Mar. 1960): 3-6.

Describes how a Boeing "shaker pot" ("little more than a glorified phonograph loud-speaker") operates and is used to vibrate missile components to test them for reliability.

Criteria: style, puns, em dashes, scare quotes, reliability theme.

“Weight Control." Bomarc Service News 9 (Apr. 1960): 3-6.

Explores the variables that affect weight in the IM-99B missile, and considers how Boeing engineers negotiate these variables; includes a historical discussion of how Duralumin reduced weight in the F2B plane.

Criteria: style, em dashes, historical discussion, ending nearly identical to that of "Missile Mockups."

"Missile Mockups." Bomarc Service News 10 (May 1960): 10-12.

Cites the importance of positioning components correctly inside the IM-99A and B missiles, and shows how engineers tackle this task using mockups.

Criteria: conversational style, em dashes, reliability theme, creative opening, ending nearly identical to that of "Weight Control," echo of $G R .11$

"Torquing." Bomarc Service News 11 (Jun. 1960): 7-9.

A study of how torque and tension influence the performance of Bomarc missiles.

Criteria: style, Latin etymology, Roman history, bullet-point arrows, reliability theme, ending nearly identical to that of "SCE Calibration."

"SCE Calibration." Bomarc Service News 12 (Jul. 1960): 14-17.

A sketch of how IM-99A missile components are calibrated, and an enumeration and description of the Service Checkout Equipment (SCE) used to do the calibration.

Criteria: Latin etymology, bullet-point arrows, reliability theme, ending nearly identical to that of "Torquing."

"Package Handling." Bomarc Service News 14 (Sept. 1960): 3-8.

Summarizes the precautions necessary in handling and transporting Bomarc component packages to avoid contamination and vibration damage; also has an extended section on safety for those who handle the packages.

Criteria: instructive tone, em dashes, bullet-point arrows, safety and reliability themes.

"Analog Simulations." Bomarc Service News 15 (Oct. 1960): 11-13.

Analyzes how analog computers allow for continual adjustments in Bomarc missile guidance during the intercept phase; discusses how simulations negotiate randomness, that is, the fact that there is "no way 
to predict how fast, where and in which direction an enemy target is coming into a defense area."

Criteria: style, em dashes, puns, reliability theme, randomness passage that echoes $G R$.

"ANFA Hazard." Bomarc Service News 15 (Oct. 1960): 16. Rpt. Aerospace Accident and Maintenance Review Jan. 1961: 9.

Discusses the dangers of handling aniline furfuryl alcohol fuel and the necessary precautions.

Criteria: conversational style, em dashes, humorous/quirky analogies in penultimate paragraph.

"1,000,000,000 Miles = One Gigamile." Bomarc Service News 16 (Nov. 1960): 8.

Defines and describes the use/usefulness of numerical prefixes such as mega-, giga-, etc.

Criteria: conversational style, Greek/Latin/French etymologies, erudite historical references, linguistic playfulness.

“Separation Diaphragms." Bomarc Service News 20 (Mar. 1961): 4-5.

Argues that care should be taken so that separation diaphragms (which ensure that liquid propellants remain unmixed during IM-99A storage) do not rupture prematurely.

Criteria: style, reliability theme, echo of "The Secret Integration."12

"Maintainability, Part 2." Bomarc Service News 21 (Apr. 1961): 8-12."13

Stresses the need for "hard-headed, realistic and field-oriented" maintainability as a principle of design; defines ten crucial maintainability principles, such as recognizability, accessibility, interchangeability, etc.; opens with a page-long fictional exchange between a "bird colonel" and a "junior management type" discussing an imaginary case of maintainability gone seriously awry.

Criteria: conversational/instructive tone, em dashes, Latin etymology, reliability and maintainability themes, reference to the maintainability "bible," creative opening.

"Lessons from the Launchers." Aerospace Safety 17.5 (May 1961): 16-19. ${ }^{14}$

Recaps trends in hazardous-chemical and launching-equipment accidents at Bomarc sites in 1960, then describes Boeing's new safety measures; argues that imaginative maintenance and common sense are the two factors most necessary to prevent future mishaps.

Criteria: conversational/instructive tone, em dashes, safety theme, ending parallel to that of "Maintainability, Part 4."

"Maintainability, Part 3." Bomarc Service News 23 (Jun. 1961): 8-10.

Focuses on maintainability at the tactical level; describes how the IM-99B Maintainability Review - a landmark maintainability study - was compiled, and what media were used for reporting and analysis.

Criteria: style, em dashes, maintainability theme. 
"Soldering." Bomarc Service News 25 (Aug. 1961): 3-10, 16. Rpt. Aerospace Accident and Maintenance Review Apr. 1962: 2-9. ${ }^{15}$

A tour de force on issues including the composition of solder, proper pre-cleaning, heating, procedures and tools necessary for both conduction soldering and resistance soldering, and final inspection.

Criteria: conversational/instructive tone, em dashes, Greek etymology, beer humor, reliability theme, Calkins's recollection.

“Maintainability, Part 4." Bomarc Service News 26 (Sept. 1961): 3-8.

Discusses the five major benefits of the IM-99BMaintainability Review: that it streamlined the previous maintenance plan, instituted particular hardware fixes, forewarned personnel of recurrent maintenance difficulties, resolved safety problems and provided information for future maintainability efforts.

Criteria: instructive tone, em dashes, maintainability theme, reference to the maintainability "Book," ending parallel to that of "Lessons from the Launchers."

"Missile Ground Support Equipment." Aerospace Accident and Maintenance Review Dec. 1961: 2-6.

An extensive summary of the ground support necessary for launching the IM-99A and B missiles, including transportation, service, shelter, testing and safety procedures; also contains a historical section on the $\mathrm{V}-2$ rocket that describes the equipment found at $V-2$ launch sites.

Criteria: conversational/instructive tone, em dashes, Latin etymology, safety, reliability and maintainability themes, reference to the groundsupport equipment "Book," $\mathrm{V}$-2 discussion that echoes $G R .{ }^{16}$

"Attention to Detail." Bomarc Service News 30 (Jan. 1962): 8-10.

Stresses the importance of noticing details, the ways errors occur (oversight, interchange, faulty evaluation, etc.) and the problems errors may cause.

Criteria: conversational/instructive tone, em dashes, ellipses, bulletpoint arrows, reliability theme.

"Teflon' in Depth." Bomarc Service News 31 (Feb. 1962): 3-4, 13.

Discusses the history, composition, uses and attendant dangers of Teflon; especially and repeatedly emphasizes the danger of smoking around it.

Criteria: style, ellipses, safety theme, quirky opening passage, jokes about smoking, historical references (especially to Du Pont), echoes of GR. "The Mad Hatter and the Mercury Wetted Relays." Bomarc Service News 31 (Feb. 1962): 16.

A historical and practical discussion of the dangers of using mercury; tells what to do if "mercury wetted relays" letched cards used in the IM-99B IMSOC rooms) explode and spew mercury. 
Criteria: instructive tone, em dashes, bullet-point arrows, quirky historical and literary references, safety theme.

"MIU Plug Problems." Bomarc Service News 33 (Apr. 1962): 4-7.

Outlines problems associated with plugs for Mobile Inspection Unit cables, such as mismating of plugs and receptacles, contamination, and damage from dropping or banging.

Criteria: style, instructive tone, em dashes, bullet-point arrows, reliability theme.

"The Trouble with Safety Is . . People!" Approach: The Naval Aviation Safety Review May 1962: 29. Rpt. Bomarc Service News 37 (Aug. 1962): 12. ${ }^{17}$

Cites people, not just unsafe conditions, as the primary agent responsible for many industrial accidents.

Criteria: style, ellipses, safety theme, poem.

"Environmental Protection." Bomarc Service News 36 (Jul. 1962): 3-8. ${ }^{18}$

Details measures that are taken and should be taken to protect missiles and missile components from environmental hazards, specifically contamination, weather, vibration and shock.

Criteria: conversational/instructive tone, em dashes, ellipses, scare quotes, reliability and maintainability themes.

"Hydrazine Tank Cartridge Replacement." Bomarc Service News 38 (Sept. 1962): 3-5.

A guide to handling hydrazine and to safety procedures in case of spills or vapor exposure; includes a historical discussion that links Bomarc hydrazine to the hydrazine hydrate used in V-2 rockets.

Criteria: conversational/instructive tone, em dashes, bullet-point arrows, smoking/vapor and other humor, safety theme, V-2 references. "Bomarc Reliability and You." Bomarc Service News 39 (Oct. 1962): 3-8.19

Argues that the reliability of Bomarc missiles depends most on the diligence of Air Force technicians rather than on any machine testing, so technicians must always strive to be $100 \%$ reliable in their work.

Criteria: conversational/instructive tone, em dashes, reliability and maintainability themes.

Possible Pynchon Articles ${ }^{20}$

"Telemetering: Recovery, Recording, Reduction." Bomarc Service News 16 (Nov. 1960): 13-17. ${ }^{21}$

Describes gathering and processing missile flight-data (temperature, pressure, voltage, etc.); the conclusion stresses the importance of telemetering during tests, while conceding its relative uselessness in tactical situations.

Criteria: conversational style, em dashes, Greek etymology, reliability theme. 
"Missile Sealants." Bomarc Service News 17 (Dec. 1960): 5-9.

Discusses the chemical composition of sealants, lists and defines a number of seal types, and provides a step-by-step guide to the process of sealing.

Criteria: instructive tone, em dashes, bullet-point arrows.

"Blame It on Osmosis." Bomarc Service News 18 (Jan. 1961): 3-7.

Explains osmosis and a new procedure that negates its damaging effects on oil in the roof hydraulic system of Model II missile shelters.

Criteria: conversational style, em dashes, quirky analogies, safety theme.

"Records Prove Valuable." Bomarc Service News 24 (Jul. 1961): 9, 13.

Advises Boeing personnel to contact a Technical Representative before filing an Unsatisfactory Report about an out-of-tolerance condition in a rocket.

Criteria: conversational style, em dashes, reliability theme.

"Of Astronauts and Acid." Bomarc Service News 24 (Jul. 1961): 16. Rpt. Aerospace Accident and Maintenance Review Oct. 1961: 9.

Because of recent safety violations/accidents on the ground, cites the precautions astronauts take when handling acids.

Criteria: instructive tone, ellipses, safety theme, literary wordplay in title.

"Transporter-Loader Hoist Safety." Bomarc Service News 27 (Oct. 1961): 5.

Describes an accident involving the IM-99B's transporter-loader hoist system, and describes the remedial measures taken.

Criteria: style, safety theme.

“IM-99B Flyaway Kits." Bomarc Service News 30 (Jan. 1962): 11, 13.

Describes how and why $\mathrm{IM}-99 \mathrm{~B}$ missiles are delivered to bases piecemeal (in "flyaway kits") and recounts how Second World War gremlins are responsible for any component shortages.

Criteria: conversational style, em dashes, gremlin humor.

"Vent Those Tanks!" Bomarc Service News 32 (Mar. 1962): 16.

Advises that tanks be depressurized before being serviced; describes two incidents.

Criteria: instructive tone, em dashes, safety theme.

"A Blinding Flash." Bomarc Service News 34 (May 1962): 12. Rpt. Aerospace Accident and Maintenance Review Dec. 1962: 27.

Analyzes an accident in which three Bomarc workers were temporarily blinded by an electric arc during work on a troublesome motor.

Criteria: instructive tone, bullet-point arrows, safety theme.

"Safety Devices?" Bomarc Service News 39 (Oct. 1962): 12.

Discusses why safety devices do not provide safety if used improperly. Criteria: instructive tone, safety theme. ${ }^{22}$ 
Notes

'Edward Mendelson, it seems, was the first to publicize "Togetherness," a decade earlier. See the bibliography in his Pynchon (223), where, however, the page numbers are given as $6-18$.

${ }^{2}$ The address is corroborated by a letter from Pynchon to Candida Donadio dated November 2, 1961. Unlike Winston and Cowart, however, Fry gives Pynchon's starting date at Boeing as February 22, 1960, rather than February 2.

${ }^{3}$ To be precise, the first three issues of Bomarc Service News were published by Boeing's Pilotless Aircraft Division. In late 1959, however, Boeing's Seattle and Pilotless Aircraft divisions and its Systems Management office joined to form the Aero-Space Division (see BSN 4: 2).

${ }^{4}$ In addition, I had to sign a form which stipulated the following: "We will provide the copyrighted materials requested for your personal research only. Please understand that this approval does not permit you to reproduce the materials, distribute them substantially, or use them for any commercial purposes. You may reference and quote from the materials in your article with appropriate attribution."

"Namely, March 1960 to October 1962. As the "Received" stamps on the covers of the NASM copies indicate, the newsletter was published around the first of its cover month, and so was presumably written during the preceding month. That is, articles written in February, for example, would appear in the March issue, published around the first of March.

${ }^{6}$ Merle Dowd, who worked with Mr. Hixson on Boeing Field Service News, provided me with details regarding the creation of articles for that publication. I quote this information because of its possible relevance to the research and writing of Bomarc Service News:

On the BFSN Ed Hixson would assign a topic to be researched, usually as a result of letters from field service engineers. I would research the problem, which may have required talking with some member of the engineering staff, maintenance of flight personnel at the flight line or other field service engineers. If the subject was approved on the basis of my preliminary research, I would write the article and submit copies to the sources I had contacted for their approval. I frequently rewrote portions of articles to conform to changes suggested by engineers or others. The article would then be scheduled for publication by Mr. Hixson. (L)

${ }^{7}$ Fifteen articles by members of the Bomarc Service News staff appear in Aerospace Accident and Maintenance Review for 1960-1962. Most are reprints from Bomarc Service News and are credited only as such, but three are signed-two by Albert S. Fournier and one by Michael A. Lear. Aerospace Safety for 1960-1962 has three articles by Bomarc Service News staff"Togetherness," one by Albert H. Hicks, and one anonymous (for the last of 
these, see the annotated bibliography and note 14). Mr. Hixson confirmed these names, for a total of four out of the five to six writers on the Bomarc Service News staff. Unfortunately, I was not able to locate any of these other men.

${ }^{8}$ In the first issue of Bomarc Service News, Lysle A. Wood, the VicePresident and General Manager of what would become the Aero-Space Division, outlines the newsletter's purpose and methods:

We found that there is no substitute for this type of publication as a means of providing advance technical information on operation, maintenance, changes, safety procedures, and general information regarding a weapon system.

The editorial staff utilizes the technical resources of the entire Boeing Airplane Company during preparation of material to be released in this publication.

It is intended that the BOMARC SERVICE NEWS will in no way conflict with official information contained in Air Force publications and authorized technical manuals or Boeing documents or drawings. The primary objective is to furnish advance technical information and general information not covered by official publications. (BSN 1: 3)

${ }^{9}$ Pynchon's fiction is well known for incorporating urban legends, folk- and other tales. For example, $V$. has the boy with the golden screw in his navel, and the alligators in the sewer. Gravity's Rainbow has "Automotive Age Myth or some shit" (581), and two echoes of the most striking locution in the rumor passage: "remember all those guy-goes-to-the-doctor-can't-get-a-hardon jokes?" (581); and "Remember the story about the kid who hates kreplach?" (737). A children's rhyme quoted in Gravity's Rainbow (177) prompts Mendelson to note the historical fact of its astonishingly rapid oral transmission (GE 187), that is, on a phenomenon quite similar to the mysterious proliferation of rumors mentioned in the Teflon article.

${ }^{10}$ Authorship of these ten is hard to determine, but $I$ include them for the record.

"The technical material in "Missile Mockups" seems to echo the description in Gravity's Rainbow of Franz Pökler's work on "Halbmodelle" of the rocket (GR 402).

${ }^{12} \mathrm{As}$ the article notes, separation diaphragms are also known as burst diaphragms. In Pynchon's short story "The Secret Integration" (1964), Grover Snodd designs a grenade that incorporates just this kind of diaphragm: "A sodium grenade: two compartments, sodium and water, separated by a burstdiaphragm. When the sodium came in contact with the water, it would go off with a tremendous bang. But the diaphragm was too strong or something, and it wouldn't break" (SL 144).

${ }^{13}$ Part 1 in this series appears in the July 1960 issue of Bomarc Service News, but Pynchon seems to have had no hand in it. Incidentally, as Mr. Hixson writes in an editor's note, this series on maintainability "is in its way a 
milestone in the relatively brief history of maintainability. It's the first time to our knowledge that any contractor has been paid by the Air Force to come up with an evaluation of how maintainable his own weapon system actually is" (BSN 26: 2).

14"Lessons from the Launchers" is credited only as "Reprinted From Bomarc Service News," but it does not appear there. Melanie Jackson, Pynchon's agent, has denied that Pynchon wrote this article (L). But I list it as "Probable" because its style seems consistent with that of the other articles I attribute to Pynchon. "Lessons" also refers explicitly to "Togetherness."

${ }^{15}$ Although internal references to past or future Bomarc Service News articles are rarely useful for locating Pynchon articles, "Soldering" (known from Calkins's recollection to be by Pynchon) does refer to the upcoming "Teflon' in Depth."

${ }^{16}$ The first references to the V-2 in Bomarc Service News occur in two articles in the October 1959 issue, "The Numbers Game" (BSN 4: 8-10) and "Solid Propellant Motor" (BSN 4:13-16). The articles would seem to be several months too early to have been written by Pynchon, and internal evidence also suggests that he wrote neither of them. But it is reasonable to assume he read both as part of his work for Boeing. The opening paragraph of "The Numbers Game" is especially relevant to Gravity's Rainbow:

It began at Peenemünde. During the more than 3,000 test firings of the V-2 rocket, this small village on the N.E. coast of Germany became the cradle of modern missile systems. Here, in the hectic days near the end of World War II, the idea of statistical prediction of the probability of success was born. Since then, methods for predicting and influencing reliability have grown spectacularly. Bomarc required less than 100 firings before it was considered ready for operational use. (BSN 4: 8)

${ }^{17}$ According to a Bomarc Service News editor's Note, "This article (with a little of the salt removed) is reprinted courtesy of 'Approach' magazine" (BSN 37: 12). The style, however, seems consistent with Pynchon's: for example, "Judging from the stories people tell about industrial accidents, one would think that the tools and equipment we use are alive; that they are aggressive and sinister objects that are ever ready to pounce upon us and inflict injury." Also, this article is unique in the pages of Bomarc Service News in that it contains a poem, which I quote in full:

It's not the wrench that slips and strikes

Or the circuit you thought was dead;

It's not the machine that grabs your hand

Or the stairs with the slippery tread;

It's not the hole that you fall in,

So please don't be misled;

The thing that causes the accident is YOU-

Not using your head. (BSN 37: 12) 
There are some minor differences between the Approach and Bomarc Service News versions of the article.

${ }^{18}$ Although this article includes a list of some eighty articles on environmental protection that have appeared previously in Bomarc Service News, it refers otherwise to only two, "Vibration Testing" (March 1960) and "Package Handling" (September 1960), both of which I attribute to Pynchon.

${ }^{19}$ This article begins by discussing the (now notorious) Soviet downing of an American U-2 spy plane over Sverdlovsk on May 1, 1960, and includes an excerpt (in translation) from Pravda which recounts the incident. I quote the second half of this excerpt because of its possible relevance to Gravity's Rainbow:

Corporal Kharbargin faultlessly plotted the target flight on a map. Major Mikhail Voronov at the command post was given precise parameters of the target, then gave the order to fire.

The rocket shot through the air, shaking all things around and leaving a fiery trace. Then there was an explosion in the sky, meaning destruction of the American plane . . . (BSN 39: 3; ellipsis in original)

${ }^{20}$ At least three Bomarc Service News articles that predate Pynchon's reported time at Boeing exhibit characteristics of the Pynchon Bomarc Service News style as I have described it: "Don't Panic" (January 1960), "XIM-99B Explosive Items" (January 1960) and "Boeing's Missile Training School" (February 1960). This fact suggests, on the one hand, that Pynchon may have begun working at Boeing earlier than Winston claims, or, on the other hand, that there may have been another member of the Bomarc Service News staff whose writing (at least sometimes) resembles Pynchon's. Needless to say, the latter possibility problematizes the identification of Pynchon articles. It would also support Melanie Jackson's denial that Pynchon wrote "Lessons from the Launchers."

${ }^{21}$ Pynchon may have written the "Conclusion" section of this article.

${ }^{22}$ I wish to thank E. A. Hixson, who kindly, patiently and repeatedly answered all my questions about Bomarc Service News. I am also grateful to Mary Kane and Michael Lombardi of Boeing, to Bob Dreesen of the National Air and Space Museum Archives, to Merle Dowd, former writer for Boeing Field Service News, and to Lindsey Kordis, Kat Paulson and Elizabeth Maxwell, all of whom helped make this essay a reality. Finally, I thank the Graduate Center of the City University of New York for helping fund my research.

\section{Works Cited}

"Boeing LGM-30A 'Minuteman I.'" United States Air Force Museum, WrightPatterson AFB, Dayton, $\mathrm{OH}<$ http://www.wpafb.af.mil/museum/outdoor/ od6.htm>.

"A Brief History: Bomarc." Boeing < http://www.boeing.com/companyoffices/ history/boeing/bomarc.html >. 
Calkins, Kenneth. "Roundel for Bomarc." Boeing Magazine Oct. 1961: 12-13. Cowart, David. Thomas Pynchon: The Art of Allusion. Carbondale: Southern Illinois UP, 1980.

Dowd, Merle. Letter to the author. 2 Sept. 2002.

Fry, Donn. "A Genius Among Us-For a While." Seattle Times/Seattle PostIntelligencer 14 Jan. 1990: L7.

Hixson, E. A. Letter to the author. 4 Apr. 2002.

---. Letter to the author. 2 Jun. 2002.

---. Letter to the author. 8 Jun. 2002.

Jackson, Melanie. Letter to John M. Krafft. 18 May 1999.

Lane, Richard. “Boeing, Boeing." The Pynchon Files < http://web.archive.org/ web/*/http://www.pynchonfiles.com $>$.

Lombardi, Michael J. Letter to the author. 26 Feb. 2002.

---. Telephone conversation with the author. 25 Feb. 2002.

Mead, Clifford. Thomas Pynchon: A Bibliography of Primary and Secondary Materials. Elmwood Park, IL: Dalkey Archive, 1989.

Mendelson, Edward. "Gravity's Encyclopedia." Mindful Pleasures: Essays on Thomas Pynchon. Ed. George Levine and David Leverenz. Boston: Little, Brown, 1976. 161-95.

---, ed. Pynchon: A Collection of Critical Essays. Englewood Cliffs, NJ: PrenticeHall, 1978.

Nichols, Lewis. "In and Out of Books." New York Times Book Review 28 Apr. 1963: 8 .

[Pynchon, Thomas.] Anonymous articles. See the annotated bibliography above. Pynchon, Thomas. Gravity's Rainbow. New York: Viking, 1973.

---. Letter to Candida Donadio. 2 Nov. 1961. Joseph Heller Collection. Brandeis $U$, Waltham, MA.

---. Slow Learner. Boston: Little, Brown, 1984.

---. "Togetherness." Aerospace Safety 16.12 (1960): 6-8.

---. V. 1963. New York: Perennial, 1986.

Reidinger, Thomas. "Minuteman." Boeing Magazine Nov. 1959: 10-11.

Schaap, Dick. "No Return Address on the V-Mail." Book Week 10 May 1964: 6.

Winston, Mathew. "The Quest for Pynchon." Twentieth Century Literature 21.3 (1975): 278-87. 